\title{
The Plan and Developing Direction of the Japanese English Education System in the New Era
}

\author{
Yan Teng \\ School of Language and Literature \\ Harbin Institute of Technology, Weihai \\ Weihai, China
}

\author{
$\mathrm{Li} \mathrm{Li}$ \\ School of Language and Literature \\ Harbin Institute of Technology, Weihai \\ Weihai, China
}

\author{
Wei Qu \\ School of Language and Literature \\ Harbin Institute of Technology, Weihai \\ Weihai, China
}

\begin{abstract}
Since the 21st century, there has been an upsurge of English education reform in Japan and a series of English education reform policies and measures have been introduced. Japan's top-down dominance has made the English education reforms in elementary schools, junior high schools, high schools, and universities more longitudinally coherent, effectively linking the various academic sections and ensuring the smooth implementation of reforms. The "one-stop" education system for primary school, middle school, high school and college English teaching has been implemented. This paper analyzes the planning, reform measures and development direction of Japan's primary school, middle school and college English education system, and draws some useful lessons from it, hoping to provide inspiration for the reform of English teaching in China.
\end{abstract}

Keywords-Japanese English; education system; reform measures

\section{INTRODUCTION}

Today, the economy and society are rapidly developing toward globalization. In response, the international competition is becoming increasingly fierce and the interdependence is also deepening. To survive in the international community, it is necessary to have a broad perspective and international understanding and coordination capabilities. As an international language, English is the key to sustaining this relationship and improving the international survivability. Therefore, English education has received the attention of countries. Among them, Japan has made great efforts in the reform of English education. It has taken a series of actions and has issued many policies and measures for the reform of English education and teaching. Since 2000, Japan has widely listened to the views of people of insight through such forms as "the Talkfest of Promoting the Improvement of English Guidance Methods" and "the Talkfest of English Education Reform". In 2002, it formed "the Strategic Concept of Training Japanese People Who Can Use English" and afterwards, "the Action Plan for Cultivating the Japanese Who Can Use English" was formulated, which clarified the goals and direction of the English education reform and the concrete measures taken to achieve the goal. Recently, it also announced guiding essentials for new English language learning, providing guidance on the consistency of the links between the various academic passages, setting targets for English language ability to be achieved in each academic passage, and strengthening collaboration between adjacent academic passages in order to promote to achieve real improvement of the English ability in the each academic passage. Japan's top-down teaching reforms in English education have greatly promoted the development of English education in the country [5].

\section{PlanNING OF THE JAPANESE ENGLISH EDUCATION SYSTEM IN NEW AGE}

\section{A. The Planning of Japanese Elementary English Education in a New Era}

The value orientation of English education in primary school mainly allows children to experience foreign languages and foreign cultures, develop an attitude of active communication in foreign languages to play a foundation for the development of communication skills in secondary schools Foreign language activities in primary school do not directly teach English knowledge and training skills, but make children perceive language through various activities to inspire children's desire for knowledge of English and motivation to use English to communicate and develop the qualities of communicating in English, preparing well for regular English study in secondary schools.

1) The characteristics of Japanese English education in primary school: In Japan, the primary schools are basically using the cooperative teaching model of the class teacher and foreign teachers. The foreign teachers show the language and the foreign culture vividly to the students through personal example and verbal instruction, and use the standard pronunciation and correct grammar to show them, creating a 
chance to communicate directly with the native speakers of English.

The primary school in Japan has a theme every month from April to March of the following year. English tutors will focus on topics to lead students in various activities. In order to do a good job in primary school English teaching, each prefecture will choose a university and set up an English education center there with the task of studying English teaching methods in primary schools and provide assistance to English instructors. The Ministry of Education, Culture, Sports, Science and Technology has also designated a number of primary school English education research schools to conduct pilot projects, explore teaching methods, and provide observation sites for other elementary schools.

Many elementary schools in Japan regard parents as educational resources and establish the PTA (Parent Teacher Association) to promote communication between parents and children. Every year, many foreigners from all over the world come to Japan. The Japanese education community regards the opportunity of communicating with foreigners as a rare educational human resource. Some elementary schools have established cooperative partnerships with primary schools abroad. Each week, under the guidance of teachers, students communicate through e-mails to apply the latest information technology to primary school English teaching.

2) The reform and development of Japanese primary school English education: The Japanese government regards primary school English education as a national strategy and constantly adjusts the primary school English education policy to meet the new needs of the society. As an economic powerhouse, the 2006 budget of the Ministry of Education, Culture, Sports, and Technology for the primary school English activity alone reached 149 million yen. In addition to state funding, many private consortiums in Japan will also invest in supporting education activities. So, Japan's physical resources for primary school English education are very substantial.

In order to increase the knowledge of foreign assistant language teachers in pedagogy and deepen their understanding of Japanese culture and education systems, the Ministry of Education, Culture, Sports, Science and Technology has taken a series of measures to provide intensive training for assistant language teachers. It mainly studies the problem of collaborative teaching and discusses the skills and strategies of collaborative teaching among Japanese primary school English teachers and assistant language teachers of English native speaker.

The Ministry of Education, Culture, Sports, Science and Technology said that it will start to revise its learning skills from 2016 onwards. English classes will begin in the third grade of primary school, and English classes will be set up as formal subjects for students in grades five and six. It is planned to implement this program from 2020 to promote the cultivation of international talents.

\section{B. The Planning of Japanese English Education of Middle School in a New Era}

1) The characteristics of Japanese English education of middle school: Japanese secondary schools draw on the achievements of primary school English activities and make effective use of these results. Japan has also established cooperation and coordination organizations for primary and secondary schools to strengthen the links between them. Teachers in primary and secondary schools observe each other's English teaching and set up experimental teaching classes with the contents of guidance skills. In Japan, there is a system of teacher rotation. This rotation is not only the same-level transfer among elementary schools, but it may also be the level-shifting between junior high school and elementary school. Moreover, this transfer is not limited to a small area, but it is performed in a wide range throughout the city. This brings great benefits to the convergence of the curriculum of primary and secondary schools, and breaks the concept of the region, so that the educational resources among the regions can be well balanced.

In the early and senior high school English teaching, the guidance of a small number of teachers (ie, small class teaching) and individual guidance of proficiency levels are actively employed to form advanced schools for English education in the community. The Ministry of Education, Culture, Sports, Science and Technology also emphasizes that students should be flexible in the selection of teaching materials, and achieving supplementary teaching in light of their different English learning willing and learning levels. Teaching students should be in accordance with their aptitude. With the advent of the information age, a recent Internet-based information and communication technology called ICT (Information and Communication Technology) has been widely used in Japanese primary and secondary school English teaching. By the school, students use the Internet to communicate with foreign students in English and form a learning community to conduct Internet discussions and studies on a topic.

The five proposals put forward by Japan for developing international communication skills in English call for the promotion of English education in all regions, the establishment of core schools for English education in each region, to foster a number of Super Science High Schools taught in English and promote some schools to offer the International Baccalaureate Program. The secondary school recognizes students' learning outcomes outside the school and expands students' English learning space. Especially in high school, not only the learning outcomes of the school, but also the learning outcomes from other high schools or even outside high school, such as public lectures held by universities, colleges, and social life learning institutions, etc. All courses that meet the appropriate level should be recognized their English single-score. Japanese high school can perform the national unified practical English proficiency test on Saturday in school, which is similar to the CET 4/6 level test of non English major in our universities, but it is much more difficult. The Practical English Skills Test (British Test) can also be 
used as a result of college admission and the confirmation of school credit.

2) The reform and development of Japanese English education of middle school: Japanese middle school English education policy is influenced by the times. However, the emphasis on the students' communication and the cultivation of their cultural comprehension has been the main principles of the English education in Japan in the past 20 years. The new essentials require that Japanese English teaching aims can be divided into learning and mastering English, cultivating the basic ability to express in English, the positive attitude of communicating in English, the interest of language and culture, and international understanding. Since 2002, the Japanese government has decided to implement a promotion policy for high school students studying abroad. It plans to provide high school students with more opportunities to study abroad in the coming years, hoping that there will be 10,000 high school students (including self-funded students) to study abroad each year. Meanwhile, the positive attitude should be taken to promote high school students' short-term international exchanges.

Japan calls the foreign education of middle school as "Assistant English Teachers."They do not carry out their teaching activities alone, but help Japanese English teachers as their assistants, namely, Japanese teachers and foreign teachers carry out cooperative teaching. This kind of "TT" (Team Teaching) teaching method has become a hot issue in the Japanese English field. At the beginning of the new century, approximately 10,000 or so foreigners went to Japan for English education as an ALT. The new strategic idea is to require foreigners to teach English to students in junior and senior high schools more than once a week. The government also plans to promote the appointment of foreigners as regular teachers. It is expected that foreign teachers will be created in junior high schools and high schools.

\section{Planning of Japanese English Education of University in a New Era}

1) The characteristics of Japanese college English education: Japan's universities propose to train international talents and education should be internationalized. So, it is necessary to vigorously promote the university's "international understanding education". Japan's international understanding education refers to the cultivation of talents with international cooperation that have both an international perspective and Japanese traditional culture through various education measures in schools. They should respect each other's position in the international community and be able to express their own ideas and meaning.

The English exam at the University Entrance Examination Center has been greatly improved with the requirement of the introduction of "hearing" and "spoken language" in the test questions. In addition, it further uses the results of a variety of off-campus English exams, such as "Practical English Skills Test", TOEFL, Cambridge English, etc. to select freshmen. There are one hundred universities selected to use the
"Practical English Skills Test" score; at the same time, universities can decide to implement "Fall Entrance" on their own, so as to facilitate the admission of foreign students and facilitate the learning of Japanese students.

It implements the "one-stop" (Japanese is called "consistent") education system for elementary, middle, high school and college English teaching. It adopts ways to strengthen communication among English teachers at elementary, middle, and high schools, and conducts cooperative research to narrow the "gap" between them. At the same time, it proposes that after students enter university, they will achieve the goal of changing "learning English" to "learning in English". It is envisaged that at the middle school stage, students can be able to understand the other party's intentions, express their own thinking. After entering colleges, students' communicative competence in their respective fields of specialization will be cultivated.

Inspire students' enthusiasm for learning. Students' learning attitude and enthusiasm is the key to improving teaching effectiveness. In order to increase students' motivation for learning, in addition to teaching in English as much as possible, measures such as creating an extracurricular English environment and allowing students to introduce Japanese culture in English should be adopted. At the same time, it is also possible to strengthen English language broadcasting on campus, increase opportunities for exchange with foreigners, provide opportunities for overseas education institutions to study, short-term studies, visit research, overseas volunteer activities, and overseas summer jobs and intern ship and other information. Students are encouraged to participate in out-ofschool English proficiency tests.

2) The reform and development of college English education in Japan: The new measures for the five proposals to develop English international communication skills include showing students the situation in which some social people use English to guide students to imagine their future English use. For example, providing students with opportunities to contact with people who work in English; allowing students to work as internships in some English-speaking jobs; offering students chances to visit Japanese overseas companies. These new initiatives allowing students to be personally on the scene are designed to stimulate students' awareness and their motivation to improve communicative competence in English.

Proper use of modern technology can make English teaching get twice the result with half the effort. For example, making use of video tape for fast reading teaching; encouraging students to use the PC to surf the Internet, use English to chat and exchange; choosing appropriate audiovisual material for centralized training; carrying out distance learning; combing with other disciplines in teaching.

For schools that develop and practice high-quality English courses among universities, especially the universities or colleges where their courses all are taught in English, the state must offer key support and it's better for the state to encourage Japanese university students to participate in special courses in English for international students. Since 2002, the Japanese government has decided to implement a promotion policy for 
college students studying abroad. In order to promote college students to study abroad, the Japanese government will also increase overseas dispatch scholarships. Through professional teacher training, teachers in Japan improve their communication-centered English teaching level. Japan implements a "professional training system for post-graduation studies" for teachers at graduate schools. English teachers can use this system to go to overseas graduate schools to improve their studies, and to strengthen inter-regional and intracollegiate teacher training and mutual learning among faculty members for common improvement.

3) The development direction of Japanese English education in the new era: The overall goal of Japanese English education in new century is to cultivate Japanese who can use English. They hope that through the improvement of English teaching and research, high school graduates can use English for daily conversations, university graduates can use English at work, and the scores of the Japanese on the exam, such as TOEFL can reach the world average.

Japan's "Talkfest of Promotion of English Teaching Reform" put forward a series of English reform proposals at the beginning of the new century, involving reforms from primary school to university, from curriculum to teacher training. The Ministry of Education, Culture, Sports, Science and Technology of Japan issued the "Strategic Concept for Cultivating Japanese People Who Can Use English," and has also launched the "Action Plan for Cultivating Japanese People Who Can Use English," clarifying the goals and directions for future Japanese English language reform and emphasizing the economic role of English. The plan requires all Japanese junior high school students to be able to perform greetings, answers and "basic" discussions on the topics related with daily life when graduating from junior high school; all high school students are required to be able to engage in "normal" discussions on the topics related to daily life when they graduate from high school; college graduates are required to be able to use English at work, and universities need to set specific goals for this purpose. The Japanese government has promulgated a basic plan for education promotion, urging the development of foreign language education and teaching at all stages of education, and proposed that foreign language education should be promoted as a national policy. After becoming a required course for Japanese middle schools, English was also accepted as a required course for Japanese elementary schools.

All kinds of English exams have gradually incorporated communicative competence, thus exerting a backwash effect on Japanese English education. The national English test examination, which is considered by the country as a test for Japanese nationals' English proficiency, has begun to be incorporated into oral English test. In the college entrance examination questions, the proportion of grammar knowledge test questions has fallen to $20 \%$. At the same time, the answers to these grammatical test questions still need certain communicative knowledge.

\section{CONCLUSION}

Japan's English education requires us to reflect on how to look at the status of English education in education. The formulation of foreign language education policy is part of the construction of the country's soft power. Japan promotes the ability of communicative competence in English to a national strategy. Through the presentation of strategic goals and action plans, it constantly pays attention to the effect of implementation and the progress of reforms, strengthening the role of English communication ability to promote Japan's integration into globalization and enhance Japan's international competitiveness in the 21 st century.

The Japanese English education reform has some prominent features worthy of reference and learning for China's English education reform. Firstly, it's necessary to attach importance to participation and experience in teaching methods, stimulate learning awareness and enhance learning motivation; the second is to teach students in accordance with their different degrees and wishes; the third is to carry out specialized teacher training and improve the teachers' ability to perform communication-centered English teaching; the fourth is to strengthen exchanges among English teachers in elementary schools, middle schools and universities and carry out cooperative research. In these aspects, we should think further, and combine our country's reality to explore an English education model that is more suitable for China.

\section{REFERENCES}

[1] Wang Yurui, Zhang Yuxiu.Japan's Strategic Conception of Cultivating "Japanese Who Can Use English"[J]. Studies in Foreign Education, 2003(10):18-20. 王玉芯,张玉秀.日本培养“能用英语的日本人”的战 略构想[J].外国教育研究,2003(10):18-20.

[2] Ohashi Harumi. The Current Situation of English Education in Japanese Primary and Secondary Schools and Its Enlightenment[J] Primary\&Secondary Schooling Abroad,2010(01):20-22. 大桥春美.日 本中小学的英语教育现状及其启示[J].外国中小学教育,2010(01):2022.

[3] Li Tianying. The Action Plan of Japanese English Education Reform[J].Studies in Foreign Education,2003(11):61-63. 李天鹰.日本 英语教育改革的行动计划[J].外国教育研究,2003(11):61-63.

[4] Zhang Liping. An Analysis of the Current Situation of Japanese English Education And Its Enlightenment[J]. Journal of Higher Correspondence Education (Philosophical and Social Science Edition), 2008(06):69-70. 张丽萍.日本英语教育现状分析及其启示[J].高等函授学报(哲学社会 科学版),2008(06):69-70.

[5] Xie Qian. International Comparative Study of Foreign Language Education Policy[D]. East China Normal University, 2011. 谢倩.外语 教育政策的国际比较研究[D].华东师范大学,2011 